\title{
Chapter 12 \\ Beloved Land, Beloved Family: The Role of Welfare in Timorese Migration to England
}

\author{
Claire C. Millar
}

\subsection{Introduction}

Timor-Leste's long history of colonisation and occupation has posed significant welfare challenges for the Timorese people. When this small, half-island nation nestled between Asia and the Pacific achieved independence in 2002, it became the twenty-first-century's first new sovereign state. Since independence, the newly founded state, nascent market and prominent third sector have focused on consolidating security and stability, alleviating poverty and laying the foundations for nationhood. Alongside these state-building efforts a budding pattern of migration has emerged, with increasing numbers of Timorese migrating to the United Kingdom (UK). An estimated 16,000-19,000 Timorese now reside in the UK, although exact numbers are difficult to calculate as most travel using Portuguese passports and are considered Portuguese citizens by the sending and receiving states (Wigglesworth 2017). Although this burgeoning migration pattern has garnered little attention, it plays an increasingly important role in the welfare of Timorese families. This chapter seeks to understand how these migrants' welfare concerns shape their decisions about geographical mobility and vice versa.

Drawing on fieldwork conducted in Oxford and Peterborough in 2017, this chapter adopts Levitt et al.'s (2017) welfare resource environment conceptualisation to study how Timorese migrants and their families piece together social protection from varied and disparate transnational sources. Levitt et al.'s (2017) theorisation is modified slightly to ensure that the analysis of family-based security regimes remains culturally situated. Adding the work of $\mathrm{Ng}$ et al. (2003) acknowledges that any conceptualisation of welfare is culturally embedded, paying special attention to how the role of family can be understood and valued differently across cultures.

\footnotetext{
C. C. Millar $(\bowtie)$

Independent Scholar, Beechworth, Australia
} 
This chapter explores the role of labour markets, states and family-based welfare provisions in Timorese migration to England. It first explores economic protections by examining unemployment in Timor-Leste, employment in the UK and labourmarket conditions in both locations. The role of the state is then considered, tracking Timorese mobility across welfare regimes. State responsibility, distrust, dependency and education in Timor-Leste are contrasted with the new provisions offered to migrants by Britain's welfare state, including the social security, taxation, healthcare, legal and education systems. Arguing that Timorese migrants utilise the labour market's economic protections and state-based welfare in support of their own, family-based protection frames, this chapter elucidates the culturally differentiated ways in which migrants and their families piece together unique welfare solutions.

\subsection{Theoretical Lens: Culturally Situated Welfare-Resource Environments}

This book illuminates the need to understand social security as increasingly constructed beyond the nation state. To examine how welfare concerns shape Timorese migration to the UK, this chapter utilises Levitt et al.'s (2017) 'welfare resource environment' framework. This heuristic tool posits that individuals 'stitch together' social protection parcels, drawing on combinations of welfare provisions from all the possible protections available to them. Studying how migrants piece together social protection from many disparate and transnational sources quickly becomes complex. Access to welfare is strongly influenced by an individual's education, skills, resources, legal status, origin country, receiving country and social networks (Levitt et al. 2017, 11). An individual's resource environment is also not fixed and static but fluid and dynamic - it changes through migration, which itself is often a social protection tool. The welfare resource environment conceptualisation helps to capture this inherent complexity, providing a framework for mapping social protection in an increasingly transnational world. Levitt et al. (2017) identify four potential sources of social protection: states, markets, social networks and the third sector. This chapter expounds upon the first three of these categories, exploring the role of the state in sending and receiving countries, as well as family. The markets category is expanded to consider economic protections more broadly, discussing the role which employment and labour-market conditions play in migrants' welfare-resource environments. It does not investigate the third sector nor informal networks other than family in detail, as they are less prominent in the results. While they play meaningful roles in welfare provision in Timor-Leste, this chapter maintains a focus on the strategies that come to the fore through migration.

However, the welfare resource environment theorisation needs slight modification for the purposes of this chapter, to ensure that the analysis of family-centred informal security regimes is culturally situated. Levitt et al. (2017, p. 5) introduce 
informal security regimes to 'fill out' the picture after consideration of state and market-based welfare provisions, describing them as especially common in developing countries where states may be weak or absent. This is certainly true to an extent in Timor-Leste, where 500 years of colonisation and violent occupation have created significant welfare challenges. The state and market fail to protect against social risk and the third sector can only reach so far. Yet family plays a key welfare role in Timor-Leste not only because the state and market fail to provide but also because it is a communal, collective society. This chapter suggests that informal security regimes do not dominate solely because other options are limited but because the cultural context places emphasis on interdependence.

Levitt et al. $(2017,11)$ also describe the 'relatively unreliable and ephemeral' nature of transnational sources that are not contractually guaranteed. They state:

\footnotetext{
Whereas laws contractually obligate states to provide for citizens, and whereas market forces ensure that the most purchased protections will be provided, there is no such security for those who rely primarily on social ties and third sector organisations, each of which can withdraw their resources at any time and without recourse for the migrant.
}

This statement reveals an ethnocentrism that is in stark contrast to the findings presented in this chapter. For Timorese migrants - who reside as Portuguese citizens in a country continuously unsure if, when or how it will leave the European Union (EU) - state support in the current climate is unreliable. With precarious positions in the labour market as low-skilled, often casual workers, economic protections tied to the market may be seen as somewhat ephemeral. This chapter demonstrates that for Timorese migrants in the UK, family is paramount to security. To see state and market-based welfare as more steadfast than informal security regimes is arguably a Western viewpoint. It is therefore imperative to ensure that any examination of informal and family-based welfare remains culturally grounded.

Special attention must be paid to how the role of family in migrants' welfareresource environments is viewed and valued differently across cultures. It is here that the work of $\mathrm{Ng}$ et al. (2003) becomes useful, in their explanation that any understanding of wellbeing is embedded within clusters of cultural assumptions and values. Often based on culture-specific moral visions, these define what is most meaningful in a given cultural setting. Most relevant to this empirical case is that members of individualistic and collectivist cultures differ in their conceptions of self-hood and emotional experiences of wellbeing ( $\mathrm{Ng}$ et al. 2003). Individualism, a moral vision that emerged in Western history from Renaissance humanism, reigns in the West. The person is seen as the primary reality and society is relegated to a derivative, second-order level of reality that is simply a collection of individuals ( $\mathrm{Ng}$ et al. 2003). Happiness is gained through self-determination: internal control and behaviour regulation are prioritised and individual autonomy is an important part of psychological wellbeing. In contrast, in communal cultures interdependence is fundamental. Society is the primary reality, with the individual a part of society. Relationships with others are paramount, as is the ability to fulfil the responsibilities associated with these relationships - happiness may be gained through meeting one's obligations to others ( $\mathrm{Ng}$ et al. 2003). 
With much research in this area conducted in Western contexts, the theories and measures developed have been understandably shaped by individualism. The welfare resource environment theorisation is no exception, leaning as it does towards a focus on the individual. There is a need to comprehend not only how individuals piece together transnational social protection parcels but also how this connects to welfare at the collective level. It is vital to both maintain awareness of the cultural values and assumptions underlying existing approaches and to understand how collective actors themselves conceptualise welfare. By utilising an extended version of the welfare resource environment framework, this chapter presents a nuanced understanding of the culturally differentiated ways in which migrants engage with labour market, state and family-based welfare provisions.

\subsection{The Case: Timorese Migration to England}

Timor-Leste's turbulent history has created significant welfare challenges. Portuguese colonisation lasted over 400 years and was marked by repression and the exploitation of human and natural resources, leaving behind little in material benefits for local people (Carroll-Bell 2015). Timor-Leste gained independence from Portugal in 1975, but after a mere 9 days, Indonesia invaded. During the following 25 years of violent occupation it is estimated that a third of the Timorese population died. An independence referendum in 1999 led to the Democratic Republic of Timor-Leste officially coming into being on 20 May 2002. Despite significant resource investment since independence, Timor-Leste's population of 1.3 million still suffers some of the worst welfare indicators in the world. TimorLeste's life expectancy at birth (69 years) is still among the worst in the region, as are the mortality ratios for mothers, infants and children under five (Carroll-Bell 2015; World Bank 2018). Around 40 per cent of the population is estimated to be living in absolute poverty, with 73 per cent living on less than two US dollars a day (Department of Foreign Affairs and Trade 2014).

Little information is available on migration trends and patterns in Timor-Leste, including limited quantitative data and scarce academic research (Almeida 2010). Yet migration is not a new phenomenon there and encompasses significant internal and international migration (Guterres 2007). The first major international emigration occurred during Indonesian occupation, with approximately 250,000 people fleeing to West Timor (Indonesia), Australia and Portugal - many staying on to build new lives. Since independence, economic reasons have replaced conflict as the main motive for international emigration. Most occurs intra-regionally, with major destination countries being Indonesia, Australia, the Philippines and Portugal (Almeida 2010). Some pathways are promoted and sponsored through bilateral government agreements, including temporary labour-migration programmes in South Korea and Australia.

Alongside formal schemes, another pattern has emerged in significant numbers of Timorese working in Europe. Because citizens of former Portuguese colonies are 
entitled to Portuguese citizenship if they were born during the period of Portuguese rule - and Portugal never recognised Indonesian sovereignty over Timor-Leste - a unique loophole exists that makes Timorese born before 20 May 2002 eligible for Portuguese citizenship. Some Timorese have taken up this opportunity, applying for Portuguese passports for the purposes of labour migration. The story then goes that in the late 1990s, a factory in Northern Ireland was seeking labour through existing migration routes from rural Portugal. A Timorese took up the offer and went to Dungannon. He told his friends, they told theirs, and a steady stream of Timorese looking for the mythical chicken factory have been arriving ever since (Peake 2014). Migration has subsequently expanded to urban centres across the UK, where an estimated 16,000-19,000 Timorese now reside (Wigglesworth 2017). Regarding the fieldwork locations for this research, the Timorese connection with Oxford began when asylum-seekers settled in the area during Indonesian occupation - an estimated 2000 Timorese now live there (McWilliam 2015). In Peterborough, the first two Timorese migrants arrived in 2002 and approximately 500 people are now registered with the Peterborough Timorese Community Organisation.

Despite drawing little attention, this trend is worth taking seriously. The value of inward remittances makes labour Timor-Leste's largest export after oil, having overtaken coffee. An estimated 43 million US dollars were remitted to Timor-Leste in 2017, with 63 per cent coming from the UK (Curtain 2018). As these data do not include cash remittances or transfers using the recently popular Moneygram, the figure is likely higher. Furthermore, increasing development is usually accompanied by increasing migration, as social and economic development amplifies people's aspirations and capabilities to migrate (de Haas 2005). This is evident in both the emigration evolving alongside Timor-Leste's post-independence development and the migration patterns of neighbours in South-East Asia and the Pacific. In Shuaib's (2007) remittance study 85 per cent of respondents stated they did not know when their overseas remitters would return, suggesting that emigration could become permanent. Overall it is likely that the importance of migration as a welfare strategy for the Timorese will only grow.

\subsection{Data and Methods}

This chapter analyses 16 semi-structured interviews completed in Oxford and Peterborough in 2017, conducted in the Tetun language. ${ }^{1}$ I am a fluent Tetun speaker due to my past experience living and working in Timor-Leste. Interviewees were recruited using snowball sampling, making contacts in England through existing networks in Timor-Leste and social media. As personal relationships were instrumental in gaining access, informed-consent forms in Tetun were used to formalise

\footnotetext{
${ }^{1}$ Tetun is the lingua franca and national language of Timor-Leste. Timor-Leste's constitution classifies Tetun and Portuguese as official languages, English and Indonesian as working languages and 18 local languages as national languages (Democratic Republic of Timor-Leste 2010).
} 
the process and emphasise the role of the researcher and care was taken to manage the potential impact on relationships if respondents were unhappy with the process.

Overt participant observation was also undertaken, resulting in over 50 hours of informal conversations and extensive field notes. This included participation in community activities such as social night and football training, spending time with migrants in their homes and sharing meals together. As many more migrants wanted to be interviewed than was feasible, time was spent listening to those whom it was not possible to formally interview, allowing them to share their experiences. The field was further expanded by conversations with migrants in London, Manchester, Great Yarmouth, Bridgwater and Northern Ireland and by discussing interviewees' prior internal migration during their interviews. Although fieldwork was conducted in England only, interviews covered respondents' pre-migration life in Timor-Leste and the impact of their migration on those remaining in Timor-Leste - the results reflect this. Interviews were transcribed in Tetun and interview data and field notes coded using Atlas.ti software. Aligning with an emphasis on migrant perspectives, data analysis used an exploratory, bottom-up inductive approach. All interviewee names used herein are pseudonyms. The background characteristics of the interviewee cohort are summarised in Table 12.1.

\subsection{The Role of Labour Markets in Welfare Provision}

Welfare concerns pertaining to economic protection, employment and labourmarket conditions were the most prominent drivers in Timorese migration to the UK. In their discussion of welfare, Levitt et al. (2017) give examples of provisions such as private health insurance, contracted childcare, property investment and the protection of workers' rights. Here the net is cast much wider, moving away from traditional definitions of market-based welfare to consider the role labour-market concerns more broadly play in Timorese migrants' welfare-resource environments in England. Interviewees had vastly different experiences with labour markets before and after migration. Unemployment in Timor-Leste and Portugal, employment and a well-developed private sector in the UK and labour-market conditions across all locations profoundly shaped mobility, as migrants attempted to piece together economic security.

\subsection{1 (Un)employment and Labour-Market Conditions in Timor-Leste}

Unemployment and labour-market conditions in Timor-Leste were central forces in this migration phenomenon. Interviewees raised unemployment as a major issue in Timor-Leste, many claiming it is the main reason people are choosing to leave 
Table 12.1 Interviewee background characteristics

\begin{tabular}{|c|c|c|}
\hline Characteristic & Category & No. \\
\hline Sex & $\begin{array}{l}\text { Men } \\
\text { Women }\end{array}$ & $\begin{array}{l}10 \\
6\end{array}$ \\
\hline Age in years & $\begin{array}{l}20-34 \\
35-49 \\
50-69\end{array}$ & $\begin{array}{l}10 \\
5 \\
1\end{array}$ \\
\hline Time in UK in years & $\begin{array}{l}<1-4 \\
5-9 \\
10-15\end{array}$ & $\begin{array}{l}8 \\
4 \\
4\end{array}$ \\
\hline Citizenship used in UK & Portuguese (since gained British citizenship) & $\begin{array}{l}16 \\
(1)\end{array}$ \\
\hline Highest level of education & $\begin{array}{l}\text { Senior high school (started university) } \\
\text { Junior high school } \\
\text { Primary school }\end{array}$ & $\begin{array}{l}14 \\
(4) \\
1 \\
1\end{array}$ \\
\hline Current residence & $\begin{array}{l}\text { Oxford } \\
\text { Peterborough }\end{array}$ & $\begin{array}{l}6 \\
10\end{array}$ \\
\hline $\begin{array}{l}\text { Previous locations of residence in } \\
\text { Europe }\end{array}$ & $\begin{array}{l}\text { Migrated via Portugal only } \\
\text { Migrated via Portugal and internally within the } \\
\text { UK } \\
\text { Migrated internally within the UK } \\
\text { No internal European migration }\end{array}$ & $\begin{array}{l}2 \\
2 \\
4 \\
8\end{array}$ \\
\hline Children and their location & $\begin{array}{l}\text { Has child/ren (in the UK) } \\
\text { Has child/ren (in Timor-Leste) } \\
\text { No children }\end{array}$ & $\begin{array}{l}7 \\
2 \\
7\end{array}$ \\
\hline Current employment in UK & $\begin{array}{l}\text { Produce or supermarket packing factory } \\
\text { Warehouse (online shopping and delivery) } \\
\text { Automotive manufacturing } \\
\text { Hospitality } \\
\text { Not working (retired; extended maternity leave) }\end{array}$ & $\begin{array}{l}6 \\
4 \\
2 \\
2 \\
2\end{array}$ \\
\hline Previous employment in Timor-Leste & $\begin{array}{l}\text { Development sector* } \\
\text { Clandestine independence movement } \\
\text { (advocacy) } \\
\text { Labourer } \\
\text { Hospitality } \\
\text { Retail } \\
\text { Security (government) } \\
\text { No previous employment }\end{array}$ & $\begin{array}{l}8 \\
1 \\
2 \\
2 \\
1 \\
1 \\
1\end{array}$ \\
\hline
\end{tabular}

Note: *The development sector includes interviewees with combinations of experience in the public sector, local non-government organisations (NGOs), international NGOs, United Nations (UN) bodies, research and religious organisations

their rai doben or 'beloved land'. However, as most of the migrants interviewed had worked in Timor-Leste prior to migrating, unemployment tended to be discussed by interviewees - such as 66-year-old Joana - as a general migration determinant:

Why are so many people from Timor-Leste leaving and coming to England? Because there's no work. So many people don't have work. That's why people are leaving in numbers you can't joke about. 
Many asserted that education does not lead to employment in Timor-Leste. They described how they had observed young Timorese graduating from university with post-graduate or Indonesian degrees, only to be unable to find work. Indeed not one of the 16 interviewees had completed university, yet all but one (who migrated immediately after high school) had worked in Timor-Leste. Six had been nonprofessionals, with women in service-industry jobs and men in construction or security. The remaining nine all had professional work in the development sector, in areas as diverse as child protection, emergency response, internal displacement, infrastructure rehabilitation, rural development, literacy, economic empowerment, disability, public health and violence prevention. Most had worked in both the public and the third sector, demonstrating that tertiary qualifications are not required for employment in government, international NGOs or UN agencies. It should be noted that the work experience of interviewees is not representative of Timor-Leste's population, indicating that migration may be selective. ${ }^{2}$ That unemployment was so often raised as a migration determinant by migrants who had themselves been employed (including immediately prior to migration) also suggests that the decision to migrate might have occurred at a family or collective level.

Even with employment, labour-market conditions in Timor-Leste were pertinent. Salaries were low across all sectors and work in the development sector in particular was often contract-based. Many described their salaries as insufficient to cover their living costs or basic household needs. A monthly government salary of US\$200 might cover food and transport but making it last the whole month is difficult, given the expense of many children, large extended families and cultural practices of giving. One interviewee described working in a government ministry where salaries were not only low but often 3 or 4 months late. For those with families engaged in agricultural work, money was even scarcer. One man described how coffee farmers could work intensively for months, only to receive 25 US cents per kilo of coffee. A family who sells a lot might receive 200 or 300 US dollars but, as the year's only income, 'All you can buy is rice'. Work and the chance to earn a decent salary were simply the greatest factors in the decision to migrate. One interviewee joked about his friends in the LGBTQ+ community in Timor-Leste who assumed that he migrated due to family and societal pressure over his sexuality; laughing, he explained that, in reality, he was just looking for money. As another so succinctly put it, 'Money is the reason we want to live here'.

The four earliest migrants, who have now been in the UK for between 12 and 15 years, had migrated via Portugal. They initially migrated for both political and economic reasons and reported being required to travel to Portugal to apply for Portuguese citizenship. Although familiarity with the former coloniser and networks of extended family and friends connected them to Portugal, language was not a factor determining migration. The Portuguese language skills of these four

\footnotetext{
${ }^{2}$ Those engaged in subsistence farming and fishing (27 per cent of Timorese aged 15-64) and those who are unemployed, not seeking work or in unpaid or informal work (42 per cent of those aged 15-64) are not represented in the interviewee cohort (La'o Hamutuk 2015).
} 
interviewees ranged from fluency to no Portuguese at all. ${ }^{3}$ They stayed in Portugal for between 5 months and 4 years, before being recruited for factory work in England. They described learning via word of mouth about employment agencies that organised factory work in the UK, providing accommodation and airport pickups and lending cash to be repaid once the migrant started work. All four named unemployment and labour-market conditions in Portugal as determinants for their onward migration to the UK. Portugal's high unemployment rates, low salaries and the kind of work available (such as cleaning) were mentioned. One man concluded that 'There are more and better opportunities in England than Portugal' and that Portugal is 'also not a well-developed country'. Thirty-five-year-old Maria said:

In Portugal there is no work. The land is in crisis, there is no work. Friends say 'Ahh, go already to England. In England there is work'.

\subsubsection{Employment and Labour-Market Conditions in England}

In England, half of the 16 interviewees were working in factories - either in produce or supermarket packing factories in Peterborough or in automotive manufacturing in Oxford. Another four worked in warehouses and delivery for online shopping and logistics companies, one at a café, one in hospital catering, one had not returned to work after maternity leave and one was retired from factory work. Other work (either interviewees' past jobs or the work of Timorese migrants not formally interviewed) included meatpacking, hospitality, hotel and supermarket work. Migrants often mentioned whether they worked through employment agencies or as permanent contract staff. Agency work was considered less desirable, as 'flexible' schedules meant shorter shifts, no guarantee of full-time hours and smaller pay packets. Many started with agencies before moving to contracts. This was employerdependent: for example, several Peterborough interviewees had successfully moved to 'permanent contracts' with a local produce packing factory, whereas those in automotive manufacturing in Oxford remained with agencies for many years. English-language skills varied, with fluency rare among interviewees. Like initial migration via Portugal, language did not appear to be promoting migration to the UK. However interviewees were aware of its importance in the labour market, noting that many Timorese were unable to ascend workplace hierarchies due to their insufficient English.

Interviewees were generally positive about labour-market conditions in England. Parents were pleased that they could work nights or weekends, so that they could look after their children or rotate childcare with their partner. Interviewees enjoyed

\footnotetext{
${ }^{3}$ Portuguese is mainly spoken by older and highly educated Timorese. Those educated during Indonesian occupation speak Indonesian alongside Tetun and local languages, while younger generations favour learning English as an additional language (East Timor Government 2012).
} 
working alongside other immigrants in multicultural workplaces, describing how people came from all over the world to the UK, where work was available to those who wanted it. This overall positivity did not mean that migrants were willing to accept just any conditions. Some moved jobs (or changed shifts) for a pay-rise or 'lighter' work, to gain new skills or due to dissatisfaction - such as discomfort with cash-in-hand restaurant work and the future problems which employer tax avoidance could bring. Many worked long shifts, typically between 8 and 12 hours. They admitted that it could be tiring and boring or, as one factory worker said, 'When the line spins, my head also spins'. Yet interviewees overwhelmingly iterated that it was worth it for the money, with difficulties disappearing once paycheck hit bank account. Wages in England were described as those with which one could transform one's life. England's comparatively abundant labour market enriched migrants' welfare-resource environments, offering new economic protections and a better quality of life, as Alitu, a 32-year-old man, confirmed:

Compare England with Timor. Because here, you have work. That's it. Therefore, you have money. You have money, you have life. If you don't have money, what are you going to do? That's all it is.

One new and novel element of migrants' welfare-resource environments in the UK was a well-developed private sector, which interviewees repeatedly noted they had not been exposed to in Timor-Leste. Only four had worked in the private sector before migration: three in small businesses and one labouring with a roadconstruction contractor. Since migrating, all 16 had worked solely in the private sector. Interviewees also observed the existence of Portuguese restaurants, Lithuanian supermarkets and halal butchers in their neighbourhoods, noting that the Timorese seemed to be the only immigrant community without businesses. This exposure certainly exerted influence, with the potential to shape future mobility. Around half of the interviewees discussed the idea of starting a business in TimorLeste, with most imagining small businesses such as a corner kiosk or building a rental property. One woman described her dream of creating her own business and providing employment for others. While working at a produce packing factory, she studied how it ran, researching how the company was built in her spare time. These experiences were connected back to work, with a well-developed private sector seen as a source from which the key protection mechanism of employment could be derived.

\subsection{State-Based Welfare Provision}

State-based welfare provisions, or lack thereof, were also shaping Timorese mobility to England. States provide social protection through numerous institutions, operating at multiple levels of government, from supranational to subnational (Levitt et al. 2017). In this section an exploration of state responsibility, distrust, dependency and education in Timor-Leste is contrasted against migrants' experiences 
with social security, public services, taxation, healthcare, legal protection and education in England.

However, it is important to first note the vital role that citizenship and the supranational EU play in this case. As all interviewees arrived in the UK on Portuguese passports, access to social protection is clearly tied to citizenship and residency status. Portuguese citizenship offers a path to the EU and England and is integral to the multi-state protection parcels that Timorese migrants piece together. For 66-year-old Joana, who had migrated via Portugal, this was clear:

Portuguese government opened the path for us to come... work in England. Portuguese government is the one that gave it to us. Portuguese government opened the door for us from Timor to come to Portugal, make our passports, make our identification cards.

Because Timorese migrants are considered Portuguese citizens by the sending and receiving states, there are no official statistics pertaining to Timorese living in the UK and little bilateral institutionalised support for migrants. Furthermore, with Brexit looming, the future of this trend is uncertain. At the time of this research, Timorese communities had appeared in the Republic of Ireland in response to the Brexit referendum and may materialise elsewhere in the EU should this pathway be restricted. According to more recent anecdotal reports from networks in TimorLeste, the queues outside Dili's Portuguese embassy - fondly known as the 'passport shop' - continue to remain long.

\subsubsection{State Responsibility, Distrust, Dependency and Education in Timor-Leste}

Interviewees described the state in Timor-Leste as a central presence in their welfare-resource environments, with overwhelming responsibility for looking after its people. Providing for vulnerable groups like the unemployed, the elderly, the disabled and the poorest of the poor was seen as a priority for the state, alongside a perceived responsibility to provide employment. Some migrants felt that these protections have not materialised and the alleged failure of the Timorese state to look after its population was a recurrent theme in interviews. One woman said that the state 'doesn't give work to people, doesn't look after people', while a young man claimed that the state does not want to 'open up work' for school leavers because it is disinterested - that it instead 'just closes its eyes to these things'. Interviewees spoke of sluggish development since independence, acknowledging that the poverty, unemployment and violence of 15 years ago still exist today. Development activities funded by overseas governments, which are conspicuous in Timor-Leste, are also a form of multi-state, transnational social protection. Some interviewees thought that the Timorese government was uninterested in or incapable of adequately providing for people without assistance from international organisations. Sabino, a 33-year-old man, stated: 
I don't really accept like, handing back to government... because if you hand it over to Timor, development will fall. Everything will go really bad.

These discussions elicited a sense of distrust of the state in Timor-Leste. Poor public administration and high government expenditure were lamented, with examples like constant overseas 'study trips' by Timorese leaders to learn about systems implemented elsewhere providing no benefit. One man described a 2016 government forum on disability rights being held in venues inaccessible to people with disabilities, exemplifying the government's perceived tendency towards talk without action. Corruption was cited as a barrier to the state's implementation of adequate welfare protection - a barrier so large that interviewees were unable to fully conceptualise how the state might develop social-security mechanisms or public services without dealing with it first. Nepotism was considered to be a particularly pervasive subset of corruption. Many described finding employment without family connections as difficult, particularly in government offices. One interviewee recognised that reducing nepotism is challenging given Timor-Leste's small population, large families and cultural norms around helping 'your people'. Interviewees bemoaned the fact that if political leaders are corrupt then the people also do as they wish, with an 'If he can do it, so can I' mentality. Nepotism and cronyism reportedly restricted access to state-provided education and healthcare. Examples included student places at the national university being based on whether the applicant had family working there, or as 22-year-old Marco described, entry to Dili's national hospital:

Every time in Timor you go to like the hospital... there is always security there. Perhaps sometimes you go they don't let you in, you don't get in. Then their family come, and they open up straight away.

Migrants' welfare concerns not only shaped their mobility - migration in turn shifted perspectives on the role of state-based welfare in Timor-Leste. Some interviewees raised dependency as an issue, claiming that their viewpoints had changed since migrating. One woman thought that the majority of Timorese are now overdependent on the state and third sector, simply waiting for the government to provide employment. She described how she and other migrants were now thinking that taking responsibility for improving welfare themselves might be more effective than waiting for the state. Migration and remittances were seen as one way they had taken development (at least at the household level) into their own hands.

Education featured prominently in Timorese migrants' decisions about mobility. Pre-migration, most interviewees had completed senior high school, except for two women whose education had ended at primary and junior high school. None had completed university, although four had started. Almost half of the interviewees (both sexes, all ages) raised financial obstacles when discussing why their education ended, with many expressing sadness that their families could not afford their education's continuance. Factors like the death of a parent or having numerous siblings often exacerbated economic barriers. War and conflict had prohibited those in their 30 s and 40s from continuing their education, while younger interviewees discussed starting university but losing interest upon seeing graduates unable to find work. 
Others claimed that they made the decision on their parent's behalf, not wanting family to take on debt when there were already many mouths to feed. As education is not currently a prerequisite for employment in Timor-Leste, but employment is vital for the provision of basic needs, some interviewees relinquished further education to prioritise the basic welfare of themselves and their families. This was sometimes mirrored in the decision to migrate. A number of interviewees were first-born children or had many younger siblings and chose to forego further education and migrate so that their siblings could continue schooling. Twenty-two-year-old Marco explained his decision:

I looked based on economy, in the household, maybe if like I'm the only one, ok I can go to school. But there are also my siblings, so I made the decision and said to my mother 'Leave it, I'll look for work'. ... If I was alone in the household I could make the decision for my parents to go into debt so I can go to school, but we're so many in our household. So I made this decision to come here to work, to look after my siblings... for me to go to school, I can't make my parents suffer more.

\subsubsection{Welfare Systems in England: Social Security, Taxation, Healthcare, Law and Education}

As in Timor-Leste, migrants saw the state in the UK as responsible for looking after its people. Interviewees were impressed that the state could provide welfare protections to its large population. One claimed that the government does not leave people 'suffering in darkness' as in Timor-Leste - in England, 'the poor are not too poor'. The perceived responsibility of the state to provide employment surfaced again, with importance placed on the idea that the state 'gave people work to do everyday'.

Interviewees depicted positive experiences with Britain's social-security system. Parents described receiving child benefits, often seen as their taxes being paid back to them. Sixty-six-year-old pensioner Joana described the support she receives:

Now I receive retirement money. The government gives me money. I receive. The government gives me a house to live in. The government gives me everything ah, free. I don't pay for anything. I don't pay for the house, don't pay for electricity, don't pay for water, don't pay to go to the doctor, don't pay to get glasses, don't pay to get the bus, everything for me, free.

A single parent recounted his experiences with the welfare system during his fight for sole custody of his daughter, the victim of domestic violence perpetrated by her mother. He described how the mother's name was replaced with 'Government of the UK' on his daughter's birth certificate, his municipal public housing and how his daughter cannot leave the UK without a social worker before the age of 18 . He saw this experience as overwhelmingly positive, as did others who described the provision of public housing, money or assistance if someone is sick or unemployed as a government looking after its people. One interviewee described home visits by child services as the government kindly checking to see if a family is OK. Migrants praised good governance and professional, uncorrupted bureaucracy. The list of 
lauded public services was long: parks and gardens, libraries, sports fields, accessible paths and jobs for vulnerable people. Local government provided interpreters for Portuguese-speakers and funding for Peterborough's Timorese Community Organisation.

Migrants recognised that the UK's taxation system was what allowed for many of these public services. They explained the insurance number system, how tax was taken out of pay, how everyone (not only the big companies) pays tax and how local governments cover the cost of services like rubbish collection by collecting rates. Workers thought that Timor-Leste could use a proper taxation system, recognising the mutual benefits for both the state and the population, such as quality statefunded healthcare. Thirty-three-year-old Sabino said:

About health, health is important. Because the hospital, like here... you work, you pay tax, you go to the doctor, everything is free. Because you've already paid tax, from your pay, your salary. In Timor, you work, there's no tax, you'll have to pay for medicine, you'll pay for everything.

Women described their positive maternal and child healthcare experiences in England, while others utilised access to state-provided healthcare for family members. One interviewee flew her mother to England for GP treatment, indicating the limitations of Timor-Leste's basic medical care.

Interviewees were also in awe of the UK's legal system. They admitted having no idea about the kinds of laws existing in England pre-migration and that the learning curve had been steep to varying degrees. Interviewees recounted both minor instances of learning to abide by the law first-hand (such as being pulled over for driving without a licence, going to court and paying a fine) and more serious incidences resulting in Timorese men serving prison sentences. The effective implementation of and respect for legal protection was particularly important. Interviewees said that although Timor-Leste has a legal system, it is not strong. They described their amazement upon realising that England's legal system is effective, the general population respects the law and that they could walk around freely. As one woman put it, 'In Timor, people aren't really scared of the police. But here people are scared of the police like they are of God'. While perhaps not traditionally identified as components of welfare, Timorese migrants were adamant that safety, stability, peace and security are protections underpinning all others. The ability to live a life free of fear and violence is vital for wellbeing in any other form.

Education was also a key facet of migrants' welfare-resource environments in England. Conversations included educational opportunities for migrants themselves (like training courses) but focused on the education of children. England's education system loomed large in the minds of the nine interviewees who were parents, as being educated in England was seen as a way to avoid a life of suffering and increase future opportunities. One couple migrated while pregnant so that the child could be born, raised and educated in England. Education was also shaping future decisions: for those with children in England, wanting their child to be educated in the UK was the single greatest factor in their plans for the future. However, parents were monitoring Timor-Leste's education system, expressing that they would prefer to be in 
Timor-Leste if the quality of education there increased. Citing inadequate facilities, the distance to schools in rural areas, the problematic issue of curricula being in Portuguese rather than Tetun and the frequent use of corporal punishment, they noted that this is unlikely to occur in the near future.

\subsection{Family-Based Welfare Provision}

Family, friends, neighbours, co-workers and others all constitute networks of social ties that offer welfare protections outside the state, market or third sector (Levitt et al. 2017). Often the very raison d'être for labour migration around the globe, family in particular shapes individual aspirations for and actual practices of mobility. Through migration, transnational actors provide for non-mobile individuals and vice versa. Family is part of a migrant's resource environment, for example by caring for children remaining at home. The migrant's transfers of remittances, knowledge and connections are simultaneously fundamental to the family. Even for those who have never left their home village, welfare provision is increasingly transnational.

This final section first explores the role of family in Timorese migration to England, demonstrating how migrants utilise increased access to labour-market and state-based protections in service of their own, family-based welfare regime. The results are then connected back to the central theoretical notions, in a discussion that aligns the focus on family with interdependence in communal cultures and contrasts it against migrants' experiences with independence. It is concluded that the economic and state-based protections offered to Timorese migrants through mobility are valued for their contribution to a framework founded on relationships and responsibility.

\subsubsection{The Role of Family: Migration Determinants, Remittances and Return}

Family plays an integral role in this case. Family-based welfare systems reign supreme in Timor-Leste, with extended families providing housing, childcare (including informal adoption), cash, employment, healthcare, education, labour and capital to one another. Twenty-two-year-old man Alex described this safety net:

Like in Timor-Leste you would never become homeless, because family will always help, look after you. Even if you don't have any money, you don't have a house, but your family has a house. You go and sleep there. Eat there, eat for free, drink for free.

Family's prominence translated into the decision to migrate, with supporting immediate and extended family undeniably at the forefront. Siku, a 28 -year-old man, and Estela, a 45-year-old woman, stated respectively: 
Yeah this decision [to migrate], sometimes to look after your family... you know the Timorese system. You can be grown up but you still need to look after your mother and father.

To more or less sustain my nieces and nephews, that's my dream.

Interviewees often said that family was their first priority, with remittances a clear example of this. Remittances were most often sent to parents and siblings but also to nieces, nephews, children and spouses. The frequency and amount varied, with newer, younger arrivals sending up to GBP 800 every month. Others remitted once every 3 or 4 months, while those who had been in the UK longer (often with their own children in England) sent GBP 100 twice a year or only when families in Timor-Leste had a specific need. The most frequently mentioned uses of remittances were food and siblings' education (including tuition fees, transport and living costs for those studying in Dili or Indonesia) followed by the education of nieces and nephews. Some families purchased protections from the market in Timor-Leste by building or fixing up houses to live in or by building a small rental property in order to secure an income stream.

The impact of remittances was also discussed in terms of family - indeed it was often hard to move away from the topic! When asked about migration's economic impact on themselves as individuals, interviewees spoke of the house they had built (which their family lives in) or their feelings of satisfaction (gained from paying for their siblings' education). Many reported improvement in their families' welfare, although the impact ranged from 'really big' to seeing remittances as 'just vegetable money' allowing improvement 'little by little'. Some noted that meeting their savings goals in England was difficult, due to family needs in Timor-Leste and the lia tradition, which obliges people to give money and resources at death, marriage and other cultural rituals. Wages and benefits accessed via the labour market and the state in the UK, when remitted home, thus form a key part of the transnational protection parcels which migrants and their families piece together.

Reflections regarding return migration also centred on family. Although no interviewees spoke of having clear plans for the future, rumination revolved around family considerations. For those with some desire to return to Timor-Leste, it was usually to be with family. A good life in Timor-Leste was described as living with family in a safe, peaceful environment, with the ability to provide for them. Connection to place, culture, food, weather, belonging and a desire to contribute to development also featured. Interviewees frequently mentioned how much they missed their family and how intensely sad or anxious not being physically close made both migrants and those at home. Migrants often wondered aloud how they could have left parents, partners, siblings and children. As one interviewee explained, 'You know how it is in Timor... when we're apart from each other, we always miss each other'.

Those who discussed staying in the UK raised the same motivation - family. As noted previously, it is here that children become an important factor, with parents seeking future protection against social risk for their children by prioritising quality education. Interviewees with children in the UK sometimes expressed a personal desire to return to Timor-Leste but insisted that their child/ren should be educated in 
the UK first. When asked about her desires for the future one mother declared 'My children will finish school. Then I'll go to Timor'. José, a 45-year-old man, similarly said:

I think a lot about going to Timor. I want to go to Timor... but first I will develop my family. When my family, my children all have success, are all in university... I can begin to give it a try in Timor.

Although interviewees discussed return migration, existing evidence suggests that they are more likely to stay, particularly once they have children in the receiving country. As Castles (2004) describes, the primary labour migrant is usually a young person intending to return once savings targets are reached - this is evident in younger, more-recent Timorese arrivals who discussed staying overseas for 3-4 years but who ultimately want to return home. Castles (2004) explains that difficulty in achieving savings targets may lead to a prolonged stay, in turn encouraging family reunion or formation. Here we see Timorese migrants who have been in the UK for 5-10 years and have formed families in England or brought children over from Timor-Leste. Although parents in this cohort anticipated return to Timor-Leste, 'Once migrants' children go to school in the new country, learn the language, join peer groups and develop bicultural or transcultural identities, it becomes very difficult for the parents to leave' (Castles 2004, 209).

In earlier sections it was suggested that decisions may be occurring at a family level, as interviewees were frequently professionals hailing from a context with high unemployment and/or had younger siblings for whom they purported to have foregone further education and migrated. Even if not technically household decisions, family is clearly central to the choices made by individuals. This is seen in the decision to migrate to support family, or to remain overseas until savings goals are met or siblings in Timor-Leste have finished school or university. It is clear that Timorese intergenerational care arrangements, in combination with the welfare provisions offered through migration, are influencing both present and future mobility. The results also showed a mother flown to the UK from Timor-Leste to visit a doctor, a child deliberately born in England in order to access quality healthcare and education, parents delaying or relinquishing return migration so that their child/ren could be educated in the UK and remittances providing protections for extended networks of relatives in England and Timor-Leste. All exemplify how Timorese migrants in England utilise migration - and the protections it brings - to support their own, family-based welfare systems.

\subsubsection{Interdependence and Independence in Culturally Embedded Welfare Provision}

The central role which family plays in Timorese migrants' welfare-resource environments aligns with the emphasis on interdependence in communal, collectivist cultures. Interdependence does not mean that people lack concern about their own 
personal value or that all relationships are focused upon equally ( $\mathrm{Ng}$ et al. 2003). The 'demands' of others do not necessarily impinge on self-need - rather, participation in social relations creates fulfilment. In communal societies people indirectly pursue the happiness of their loved ones, and meeting one's obligations in turn brings happiness ( $\mathrm{Ng}$ et al. 2003). This is clear in Timorese migrants' decisions about mobility, the importance of their ability to provide for family and their satisfaction when this is possible. The intensity of homesickness experienced also aligns with the sensitivity of individuals in collective cultures to their relationships. Even the discussions surrounding the difficulty of reducing nepotism in Timor-Leste reference the very cultural norms that underpin informal and family-based protection regimes. The individual is inherently connected to others, making kinship, social obligations and belonging fundamental (Carroll-Bell 2015).

Living in England migrants were immersed in a Western context: here distinguishing between interdependence and independence is a useful heuristic. While in communal societies the cultural imperative is to be an interdependent self, in the West it is to be an independent self ( $\mathrm{Ng}$ et al. 2003). Independence does not equal selfishness or lack of sociality but is, instead, a complex set of relationships, institutions and social practices providing people with choices, thereby creating opportunities for happiness through self-determination ( $\mathrm{Ng}$ et al. 2003). Interviewees discussed their experiences with financial self-sufficiency, learning to manage their own time, independent decision-making and travel. Earning, managing and living off one's own money was a novelty, with paying rent and budgeting to buy smart phones, clothes and cars being new experiences for most. They experienced immense improvements in the quality of housing and food - one interviewee was delighted that his body had become paler and fatter since migration because he now worked inside and ate meat. Travel was also a benefit of self-governance and taking holidays for reasons other than cultural events, funerals and family responsibilities was a new experience for some interviewees. The increased feelings of independence which Timorese migrants experienced is unsurprising, given that selfdetermination, autonomy, internal control and regulation of behaviour are important in the Western conceptualisation of selfhood ( $\mathrm{Ng}$ et al. 2003).

While migration altered Timorese migrants' access to the economic protections of the labour market and state-based welfare, the focus nonetheless remained on family and interdependence. Most interviewees noted the benefits of individualism but said that they just did not subscribe to it themselves. Some described individualism in European society as negative, while others were clear that it was part of life in the UK but not desirable for Timor-Leste. State-based protections and employment were valued most for what they provide the family. England's healthcare and education were valued not only for their benefit to the individual migrant but also for how they serve immediate and extended families. The availability of work, a highly lauded facet of migrants' welfare-resource environments in England, was valued because it increased a person's capacity to provide for family. Employment was valued because it facilitated household-level development and strengthened family life, overriding any gains in individual financial independence and selfgovernance. While younger interviewees were more likely to mention their 
newfound ability to buy consumer items or to travel, they also remitted larger percentages of their salaries. Despite living for up to 15 years in a context where the cultural imperative is independence and self-determination, interviewees gained individual wellbeing by pursuing the welfare of their loved ones.

\subsection{In Conclusion}

This chapter has shown how welfare concerns shape Timorese mobility to England and vice versa, with migration itself being a welfare strategy. In Timor-Leste, resource environments exhibited a scarcity in market and state-based provisions, with immediate and extended family playing an integral role in insuring against social risk. Unemployment, labour-market conditions and limited state protection influenced decisions about mobility for migrants as both individual and collective actors. Migration to the UK - facilitated by access to Portuguese citizenship and the EU - brought employment opportunities, improved labour-market conditions, a safe environment and the accoutrements of the British welfare state in social security, healthcare and quality education.

However, interviewees were adamant that more than the provisions offered by an employer or the state, the greatest opportunity migration provided was the capacity to improve life for themselves and their family. Although some sections focused on state responsibility, this indicates that migrants do not necessarily seek full state provision. Rather, they seek a baseline level of economic and social security, perceiving the state's role as protecting fair conditions, providing equal rights and enabling people to enjoy and build upon fundamental welfare protections. The changes to welfare-resource environments that migration facilitated altered the social protection parcels that Timorese migrants could piece together, empowering them with the capability to transform themselves and their families.

Understanding how migrants and their families give life meaning is vital to the study of global social protection. By using an extended version of Levitt et al.'s (2017) welfare resource environment framework and querying the perspectives of migrants from communal Timor-Leste living in a Western context, this chapter sought to demonstrate that how people conceptualise welfare is culturally situated. It was found that Timorese migrants in England utilise migration - and the economic and state-based protections it brings - in service of their own, family-based systems. Mobility between welfare contexts allowed access to new sources of welfare, enabling migrants to fulfil their responsibilities to family and in turn ensure their own wellbeing. Timorese migrants valued increased access to the labour market's economic protections and state-based welfare for the ways they supported a family-based framework founded on interdependence, relationships with others and responsibility. By querying the geographical mobility of Timorese migrants in England in light of their welfare concerns, this chapter has illuminated the contextual and culturally embedded ways in which migrants engage with the protections offered by labour markets, the state and family. 


\section{References}

Almeida, V. M. (2010). Overview on south-south migration and development trends and research needs in Timor-Leste. Brussels: ACP Observatory on Migration.

Carroll-Bell, S. (2015). Development alternatives in Timor-Leste: Recasting modes of local engagement. Bijdragen Tot de Taal- Land-En Volkenkunde, 171(2-3), 312-345.

Castles, S. (2004). Why migration policies fail. Ethnic and Racial Studies, 27(2), 205-227.

Curtain, R. (2018). Timor-Leste remittances update. http://devpolicy.org/timor-leste-remittancesupdate-20180327/?pdf=41448\&format=pdf\&print=print. Accessed 06 Oct 2020.

De Haas, H. (2005). International migration, remittances and development: Myths and facts. Third World Quarterly, 26(8), 1269-1284.

Democratic Republic of Timor-Leste. (2010). Constitution of the Democratic Republic of TimorLeste (English). http://timorleste.gov.t1/wpcontent/uploads/2010/03/Constitution_RDTL_ ENG.pdf. Accessed 06 Oct 2020.

Department of Foreign Affairs and Trade. (2014). Aid program performance report 2012-13 Republica Democratica de Timor-Leste. https://dfat.gov.au/about-us/publications/Documents/ timorleste-appr-2012-13.pdf. Accessed 06 October 2020.

East Timor Government. (2012). East Timor government: Languages. Retrieved from http://www. easttimorgovernment.com/languages.htm

Guterres, A. (2007). Migration and development. In D. Kingsbury \& M. Leach (Eds.), East Timor: Beyond independence (pp. 43-50). Clayton: Monash University Press.

La'o Hamutuk. (2015). TL's human development index dropping, but data is lacking. http://laohamutuk.blogspot.nl/2015/12/tls-human-development-index-dropping.html. Accessed 06 Oct 2020.

Levitt, P., Viterna, J., Mueller, A., \& Lloyd, C. (2017). Transnational social protection: Setting the agenda. Oxford Development Studies, 45(1), 2-19.

McWilliam, A. (2015, 14 April). Backing themselves: East Timorese labour migrants in Oxford. COMPAS. https://www.compas.ox.ac.uk/2015/backing-themselves-east-timorese-labourmigrants-in-oxford/. Accessed 06 Oct 2020.

Ng, A. K., Ho, D. Y. F., Wong, S. S., \& Smith, I. (2003). In search of the good life: A cultural odyssey in the east and west. Genetic, Social and General Psychology Monographs, 129(4), 317-363.

Peake, G. (2014, 23 June). Hard-working, respectful and warm... we could learn from our Timorese guests. Belfast Telegraph. https://www.belfasttelegraph.co.uk/opinion/columnists/ hardworking-respectful-and-warm-we-could-learn-from-our-timorese-guests-30377313.html. Accessed 06 Oct 2020.

Shuaib, F. (2007). Leveraging remittances with microfinance: Timor-Leste country report. Brisbane: The Foundation for Development Cooperation.

Wigglesworth, A. (2017). 01 June. In Transitional livelihoods: Timorese migrant workers in the UK. Devpolicy: Blog. http://www.devpolicy.org/transitional-livelihoods-timorese-migrantworkers-uk-20170601/. Accessed 06 Oct 2020.

World Bank. (2018). World Bank Open Data: Timor-Leste. https://data.worldbank.org/country/ timor-leste. Accessed 06 Oct 2020. 
Open Access This chapter is licensed under the terms of the Creative Commons Attribution 4.0 International License (http://creativecommons.org/licenses/by/4.0/), which permits use, sharing, adaptation, distribution and reproduction in any medium or format, as long as you give appropriate credit to the original author(s) and the source, provide a link to the Creative Commons license and indicate if changes were made.

The images or other third party material in this chapter are included in the chapter's Creative Commons license, unless indicated otherwise in a credit line to the material. If material is not included in the chapter's Creative Commons license and your intended use is not permitted by statutory regulation or exceeds the permitted use, you will need to obtain permission directly from the copyright holder. 